\title{
Importance of Logistics Service Quality in Customer Satisfaction: An Empirical Study
}

\author{
Hasan Uvet \\ School of Business, Georgia Gwinnet College \\ 1000 University Center Ln, Lawrenceville, GA 30043 \\ Email: huvet@ggc.edu
}

\begin{abstract}
To create value in logistics services to fill the expectation of customers gets more significant than ever to sustain competitiveness in the market. In this paper, considering there is a small amount of research done in logistic service quality, we aimed to investigate how logistics services affect customer satisfaction. An empirical study was made to measure logistic service quality factors; personnel quality contact, order condition, timeliness, order discrepancy handling, and operational information sharing in logistics services. Confirmatory factor analysis (CFA) and structural equation modeling (SEM) has been used in this paper to explore customer satisfaction by using the five constructs of logistics service quality. One of the contributions of this article is; it is the first time the effects of operational information sharing on customer satisfaction in logistics services was investigated under the logistic service quality framework. Customer satisfaction can be explained and improved by applying these five constructs of logistics service quality. Also, this research can help both practice and scholars to understand the fundamental elements of improving customer satisfaction. The results can be used in any firm to gain competitiveness in logistic services.
\end{abstract}

Keywords: logistic service quality, customer satisfaction

\section{INTRODUCTION}

The logistics services are not only seen as an area of cost improvements but also seen as an area to gain a competitive advantage in market, because of its role that it plays to improve customer satisfaction (Bowersox et al., 2008; Novack et al., 1995). Understanding the desires of clients and finding ways to create value for them is getting more significant than ever to be able to get a competitive advantage. Today, customers are not only demanding higher quality in products but also requiring more top excellence in service which is closely related to the concept of behavioral intentions and customer satisfaction (Bowersox et al., 2002; Parasuraman et al., 1985). It is obvious that enterprises whose activities are not concentrated on customer expectations could not manage to survive in the market. Therefore, to find the critical elements of quality of service is essential to build a longterm relationship with the customers by changing their behavioral intentions. Because of the competitiveness of the service sector, the capability of firms to figure out customers' expectations is getting more compelling. Additionally, considering logistics enterprises, to understand needs of customers and to satisfy their desires is harder than other businesses (Mentzer et al., 2001; Mentzer et al., 1999). Therefore, to follow the needs of clients getting critical for the service providers to improve new services to generate value for customers and to sustain relationships with clients.

Although a few authors investigated dimensions of LSQ, there is no consensus on the attributes of LSQ. Considering there has been little research done in LSQ, this paper aims to address the main dimensions that impact customer satisfaction in logistics service. The primary purpose of this article is to understand the concept of customer satisfaction with analysis of the LSQ factors with the perspective of service quality approach. To better our understanding of LSQ, this paper will first shed light on service quality approach (SERVQUAL) and how historically LSQ has been broadened from SERVQUAL in the literature review section. In the third section, the governance structures of LSQ, research hypotheses and its relationship to customer satisfaction are addressed. The results of the conducted survey and data analysis can be found in the fourth section. In the last part, conclusion, limitations, and suggestions for future research are addressed.

\section{LITERATURE REVIEW}

While quality is defined as a comparison between expectations and performance, service quality is defined as a measure of performance which results in customer satisfaction (Juran, 1980). Customers' quality assessment not only relies on the outcome of service but also depend on all processes of service delivery (Parasuraman et al., 1985). Parasuraman et al. (1985) introduced the five-dimensional structure of service quality (SERVQUAL); tangibles, responsiveness, empathy, reliability, and assurance. SERVQUAL is an approach to see gaps between customer perceptions and customer service (Parasuraman et al., 1985). However, Parasuraman et al., (1985) argue that the characteristics of services - intangibility, heterogeneity, and inseparability - are less invisible in logistic services. There are many studies which empirically investigate five dimensions of this SERVQUAL, and several scholars have extended Parasuraman's work to develop scales for measuring the effects of logistics service quality on customer's satisfaction (Langley and Holcomb, 1991; Bienstock et al., 1996). Since the 1980s, LSQ has gained considerable attention to customer's satisfaction (Richey et al., 2007). The relationship between enhancement in LSQ and customer satisfaction was supported by a number of empirical studies (Daugherty et al., 1998; Innis and La 
Londe, 1994; Mentzer et al., 2001). According to Mentzer et al. (1989), Logistic Service Quality consists of two elements as a marketing customer service and physical distribution service. Also, Saura et al. (2008) claim that two perspectives, objective and subjective, exist in logistics service quality: While objective perspective concerns physical distribution and subjective perspective concerns customer satisfaction in logistic service.

The utility creation through physical distribution depend on the ability of logistics services to deliver "the right amount of the product at the right place at the right time in the right condition at the right price with the right information" (Coyle et al., 1996; Mentzer et al., 1999). This view led to the development of a measure of physical distribution service quality (PDSQ). Bienstock et al. (1997) conceptualized physical distribution service quality in the three top dimensions which are timeliness, condition, and availability. Because of the pursuit of competitive advantage in the market, the concept of utility creation has broadened to the value-added operational tasks and PDSQ is viewed as only one of the component of LSQ (Mentzer $e t$ al., 2001; Mentzer et al., 1999). Mentzer et al., (1999) broadened these dimensions and Parasuraman's (1985) five dimensions of SERVQUAL to nine LSQ constructs: Personal contact quality, order release quantities, information quality, ordering procedures, order accuracy, order condition, order quality, order discrepancy handling, and timeliness. Also, these dimensions were confirmed in another study by Mentzer et al., (2001). Through these nine dimensions, they only hypothesized a direct relationship between customer satisfaction and personal contact quality, order discrepancy handling, timeliness and ordering procedures with based on one organization, DLA, providing logistics services to internal customers. In 2007, Rafiq and Jaafar (2007) tested these nine LSQ dimensions in the context of the 3PL logistics industry. Different from these nine LSQ constructs, Feng et al. (2007) come up with six dimensions, which are timeliness quality, personal contact quality, order quality, order discrepancy handling, order condition and convenience, for the LSQ of the online shopping. Bienstock et al. (2008) expanded Mentzer's LSQ model by investigating logistics information technology use and acceptance in the framework of technology acceptance model. Soh et al. (2016) examined Mentzer et al. (1999)'s nine LSQ dimension by clustering into technical and functional quality dimensions in the 3PL industry. Also, Murfueld et al. (2017) investigated the impact of availability, timelines, and condition on customer satisfaction and loyalty in omnichannel retailing. On the other hand, Kilibarda et al. (2016) examined the importance of LSQ dimensions in freight forwarding companies. They found that assessment of the level of quality of service in various market segments is different. Additonally, Sohn et al. (2017) investigated these LSQ dimensions in the semiconductor manufacturing industry and 3PL. Based on their findings, authors claim that the impact of LSQ dimensions on customer satisfaction should be considered based on the customer's position in logistics triad.

The majority of the existing literature about LSQ has focused on logistics service providers, and there has been a severe lack of research done based on the customers' perspective. Surprisingly, given the importance of logistics service quality, these LSQ dimensions has not been tested in a broad spectrum of business to consumer context. Compared with the existing literature on LSQ, it can be seen that based on the Parasuraman's (1985) service quality model the gap between "expected service" and "external communications to customers" was not investigated in existing LSQ models. Bienstock et al. (2015) highlighted lack of studies for the importance of information technology in LSQ. Because of this gap in the prevalent literature, in this paper, besides personal contact quality, order discrepancy handling, timeliness, order condition, we examined the effects of operational information sharing and tested to identify their relationships with customers' satisfaction and LSQ.

\section{RESEARCH MODEL AND HYPOTHESIS}

In this study, the research model, which is presented in Figure 1, developed based on SERVQUAL literature is consistent with Parasuraman, Zeithaml and Berry's (1985) and Mentzer and Flint's (2001) constructs. Because customer satisfaction is a fundamental consideration in assessing the quality of service, it is a significantly important issue for businesses to obtain the competitive advantage and to build long-term relationships with customers (Innis and La Londe, 1994; Aranskis and Litvinenko, 2014). Therefore, this study hypothesizes that personal contact quality, order discrepancy handling, timeliness, order condition, and operational information sharing positively affect the perception of customers' satisfaction.

\subsection{Personnel Contact Quality}

Communication between the customer and contact person is significant during the service delivery to increase the perception of clients' expectations (Parasuraman et al., 1985). According to Lehtinen and Lehtinen (1991), the service quality was evaluated by customers using three dimensions: Physical quality, corporate quality, and interactive quality. The interactive feature which is seen as an interaction among customers, contact personnel, and other customers is the essential aspect of service quality (Lehtinen and Lehtinen, 1991). Bitner et al. (1994) claims that precise understanding of clients by frontline personnel, who are a part of the contact staff, facilitate to adopt customers' expectations and needs. The essential features of service personnel, such as experience, ability to empathize with the customers' situation, desire of him/her to solve the problems during the delivery process and their approach to the interaction between customers jointly affect the perception of clients about quality of service they took (Bitner et al., 1994; Mentzer et al., 2001). Because of the importance of the interaction between customer and staff in the perception of logistics service quality, the following hypothesis is proposed about the influence of personnel contact quality on customer satisfaction.

H1: Perception of personnel contact quality positively affects customers' satisfaction. 


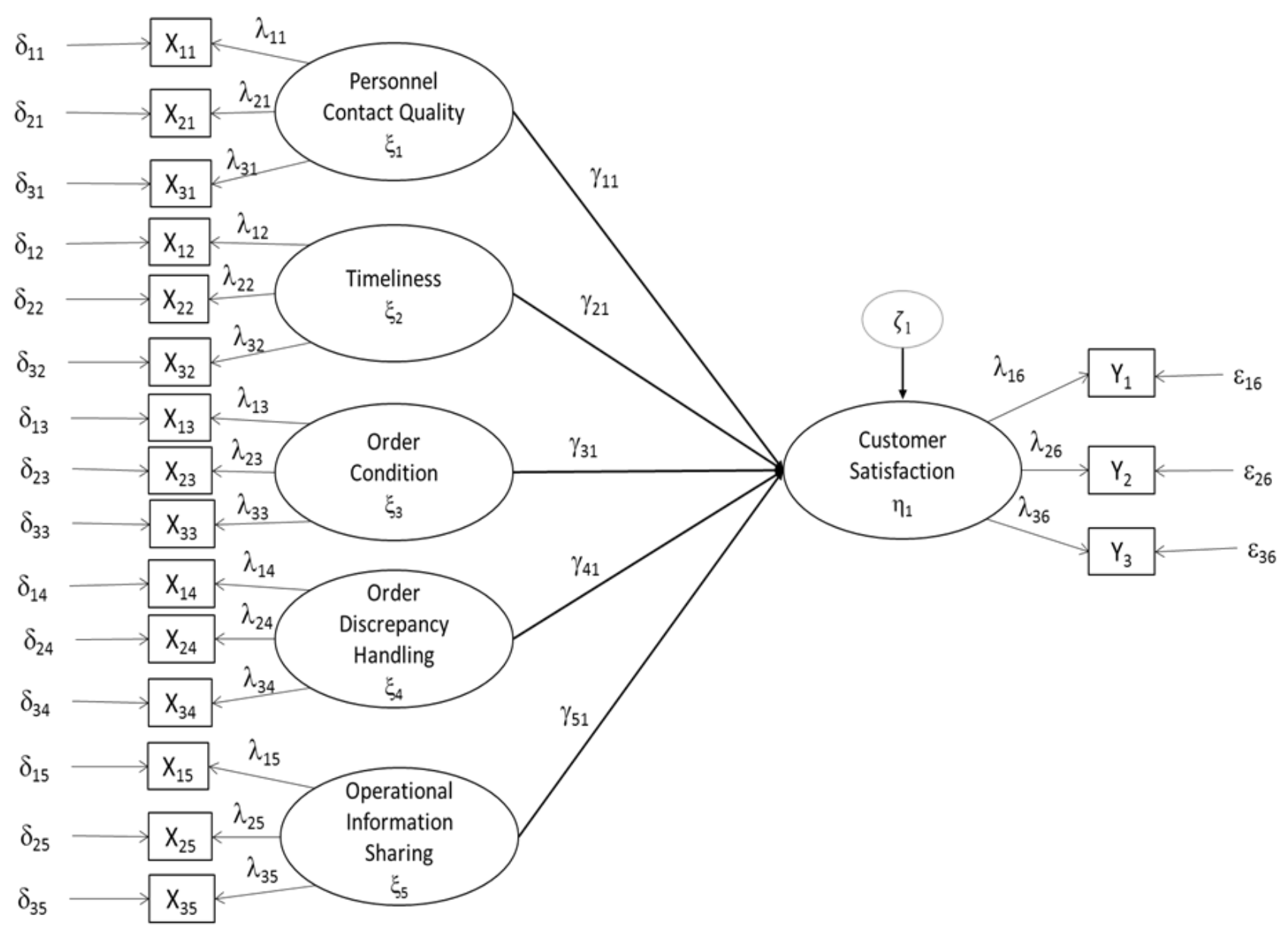

Figure 1 Causal model of the customer satisfaction in logistics services

\subsection{Timeliness}

Bienstock et al. (1996) conceptualized physical distribution service quality with three dimensions, timeliness, availability, and condition. Hult et al. (2000) define cycle time as a competitive weapon that starts from order placement to completion of delivery. This cycle time that consists of transportation time and back order time when products are not convenient is the most significant factor that shows the performance of the delivery system (Hult et al., 2000; Mentzer et al., 2001; Mentzer et al., 1999). Time utility is the most traditional and the most crucial feature of logistics service quality as much as the creation of place utility is on the perception of logistics service quality (Mentzer et al., 1999). Therefore, the following hypothesis is proposed about the influence of timeliness on customer satisfaction.

H2: Perception of timeliness positively affects customers' satisfaction.

\subsection{Order Condition}

As one of the most critical dimensions of physical distribution service quality, order condition refers to damage levels of orders during the delivery (Bienstock et al., 1996; Mentzer et al., 2001). In this study, because of the importance of order condition on the perception of satisfaction in the literature (Byrne and Markham, 1991), we hypothesized the direct relationship between order condition and customer satisfaction.
H3: Perception of the order condition positively affects customers' satisfaction.

\subsection{Ordering Discrepancy Handling}

Mentzer et al. (2001) defines ordering discrepancy handling as how logistics firms deal with differences in orders after orders arrive. The performance of logistics companies to correct discrepancies, such as wrong items and poor quality, has a significant impact on customers' perception about LSQ (Mentzer et al., 2004). Because of the significant effects of the correction of delivered conflicts on the perception of logistics service quality, the following hypothesis is proposed about the influence of the ordering discrepancy handling on customer satisfaction.

H4: Perception of the ordering discrepancy handling positively affects customers' satisfaction.

\subsection{Operational Information Sharing}

The logistics information systems which are used lately by logistic enterprises enable logistics services to increase their perception of service quality. The logistics information systems consist of internal and external information sharing. While the internal exchange of information in logistics services make it possible to increase service quality by increasing the timeliness and accuracy of orders in service, external information sharing, which includes real-time information sharing with the customers, makes it possible to close the gap of clients' expected 
service quality. The process of service delivery has great importance in expectations as much as the outcome of a service (Parasuraman et al., 1985). Because of the ability of operational information sharing to facilitate the perception of service delivery quality, the following hypothesis is proposed about the influence of operational information sharing on customer satisfaction.

H5: Perception of operational information sharing positively affects customer satisfaction.

\section{RESERACH METHODOLOGY AND DATA ANALYSIS}

\subsection{Sampling and Data Collection}

Data collection was done by undergraduate and graduate students enrolled in marketing and logistics department at the University of North Texas. An online questionnaire was used to collect data for the study. The survey was announced through the University of North Texas' College of Business faculty as well as class mailing lists. Only one sampling procedure was used to recruit participants. Any particular gender or ethnic group did not frame the sample population. Upon accessing the link, respondents were able to read a description of the survey. Some of the participants were awarded extra credit while some will not get an award for their participation. A total of 341 completed questionnaires were collected in two waves to reach a satisfactory level of response. The first wave resulted in 190 and the second wave in 151 questionnaires. After removing incomplete and carelessly completed questionnaires, under 2 minutes, 302 questionnaires were retained for subsequent analysis. A comparison between early and late respondents $\left(\chi^{2}=23.003, \mathrm{df}=17, \mathrm{p}=0.149\right)$ also revealed no significant difference. Of the 302 usable responses, the gender composition of the sample is relatively balanced with $49 \%$ male and $51 \%$ female. A comparison between female and male respondents $\left(\chi^{2}=\right.$ 13.151, $\mathrm{df}=17, \mathrm{p}=0.726$ ) also revealed no significant difference. The $83.1 \%$ percent of respondents were between 18 to $22(n=170)$ and 23 to $27(n=81)$ old. This result is consistent with our use of UNT students as the sampling frame. Appendix A presents the demographic distribution of the final retained sample.

\subsection{Materials and Construct Measurement and Reliability}

Scale items for measuring the LSQ constructs were preserved based on the existing literature (Bienstock et al., 2008; Mentzer et al., 2001). The items that measure operational information sharing were developed based on Richey and Savitskie (2007) study. The LSQ instrument contains 19 questions that are measured on a seven-point Likert-scale ( 1 = "strongly disagree," 7 = "strongly agree") (see Table 1). Of the 19 items, one question corresponds to operational information sharing (OIS4) was found low factor loading (0.64) with the other OIS items in CFA. As a result, the study uses only 18 scale items shown in Appendix B.
In this study, structural equation modeling was used to explain the relationship between customer satisfaction and the logistics service quality factors; personnel quality contact, order condition, timeliness, ordering discrepancy handling and operational information sharing in logistics services. To confirm construct reliability, unidimensionality, and validity we evaluated the five LSQ and one satisfaction constructs by using the method of CFA using AMOS. For the purpose of the discriminate and convergent validity, a structural equation procedure for obtaining correlations between latent constructs was used. We computed CR and AVE using the CFA results (Anderson and Gerbing, 1988; Bagozzi and Yi, 1988; Hair et al., 2010). A confirmatory factor analysis (AMOS) showed that the hypothesized model fit the data reasonably well (see Table 1). First, the overall fit indices for the measurement model were also acceptable results (Anderson and Gerbing, 1988; Bagozzi and Yi, 1988). A Joreskorg and Sorbom (1993) Goodness-of-Fit Index (GFI) of 0.906, a Bentler (1990) Comparative Fit Index (CFI) of 0.952, Adjusted Goodness-of-Fit Index (AGFI) $=0.87$, Root Mean Square Residual $($ RMSR $)=0.063$, and a chi-square $(\square 2)$ of 300,345with 137 degrees of freedom. Second, as evidence of convergent validity, the measurement factor loadings were all significant (t values between 9.526 and 20.601) and all the standardized $\lambda \mathrm{s}$ were above 0.5 ( $\lambda \mathrm{s}$ ranging from 0.668 to 0.903 ), the construct reliabilities (CR) were bigger than 0.70 (Hair et al., 2010) (CRs ranging from 0.758 to 0.910 ) and the average variance extracted (AVE) were above 0.5 (Fornell and Larcker, 1981) (AVEs ranging from 0.511 to 0.771 ) indicated that in each case. The variance captured by the construct was greater than the variance due to the measurement error. Third, the procedure described by Fornell and Larcker (1981) was used to test for discriminant validity, which is indicated by an AVE for each construct higher than the squared correlation between that construct and any other. As shown in Table 1, a squared correlation between any two constructs is higher than either of the constructs' AVE. Discriminant validity is supported because all the composite reliability scores on diagonal are higher than the off-diagonal correlation coefficients in Table 1. Based on the results, the evaluation form does consists of six constructs. The correlation estimates among the six latent constructs are all statistically significant. These results indicate acceptable levels of internal consistency, convergent, discriminant, and construct validity (Hair et al., 2010).

We revealed there is no significant difference between male-female and early-late groups. In each group analysis, the model fit of the unconstrained measurement models with groups loaded separately had adequate fit. Then we constrained the models to be equal, and we found that the chi-square difference test to be non-significant ( $\mathrm{p}$-value $>0.05)$. A comparison between female and male respondents $\left(\chi^{2}=13.151, \mathrm{df}=17, \mathrm{p}=0.726\right)$ also revealed no significant difference. A comparison between early and late respondents $\left(\chi^{2}=23.003, \mathrm{df}=17, \mathrm{p}=0.149\right)$ also revealed no significant difference. 
Table 1. Evidence of reliability and construct validity

\begin{tabular}{|c|c|c|c|c|c|c|c|c|}
\hline & $\overline{C R}$ & AVE & $\mathrm{OC}$ & $\overline{P C Q}$ & $\bar{T}$ & $\mathrm{ODH}$ & OSI & $\mathrm{S}$ \\
\hline$O C$ & 0,840 & 0,639 & 0,799 & & & & & \\
\hline $\mathrm{PCQ}$ & 0,869 & 0,689 & 0,442 & 0,830 & & & & \\
\hline $\bar{T}$ & 0,758 & 0,511 & 0,260 & 0,451 & 0,715 & & & \\
\hline $\mathrm{ODH}$ & 0,865 & 0,682 & 0,446 & 0,661 & 0,544 & 0,826 & & \\
\hline OIS & 0,845 & 0,580 & 0,518 & 0,563 & 0,539 & 0,672 & 0,762 & \\
\hline$S$ & 0,910 & 0,771 & 0,484 & 0,608 & 0,563 & 0,606 & 0,735 & 0,878 \\
\hline
\end{tabular}

CFA global fit indices: chi-square $=300.345 ; \mathrm{df}=137 ; \mathrm{p}$-value $=0.00 ; \mathrm{GFI}=0.906 ; \mathrm{AGFI}=0.87 ; \mathrm{NFI}=0.94 ; \mathrm{CFI}=0.952 ; \mathrm{RMSEA}=0.063$. The diagonal elements are $\sqrt{ } \mathrm{AVE}$ and the off-diagonal elements are $\varphi$ estimates.

$\mathrm{OC}=$ Order Condition, $\mathrm{PCQ}=$ Personnel Contact Quality, $\mathrm{T}=$ Timeliness, ODC= Order Discrepancy Handling, OIS= Operational Information Sharing, $S=$ Satisfaction

\subsection{Analysis and Results}

The last stage of the analysis examines the causal relationship between latent constructs (see Figure 1). The results of the analysis are presented inTable 2 . The fit indices, indicate a satisfactory model fit $\left(\chi^{2}=267.015, \mathrm{df}=\right.$ 120, Goodness-of-Fit Index (GFI) $=0.912$, Adjusted Goodness-of-Fit Index (AGFI) $=0.875$, Root Mean Square Residual $($ RMSR) $=0.064$, Bentler and Bonett's Normed Fit Index $(\mathrm{NFI})=0.921$, Bentler and Bonett's Comparative Fit Index $(\mathrm{CFI})=0.955)$. The path coefficients $\left(\lambda_{s}\right)$ capture the effects of latent constructs on the observed variables (Xs and Ys). The focus of this study is the beta and the gamma estimates since this capture the hypothesized causal relationship between the endogenous variables $\left(\eta_{1}\right.$ customer satisfaction) and exogenous variable $\left(\xi_{1}-\right.$ personal contact quality, $\xi_{2}-$ timeliness, $\xi_{3}-$ order condition, $\xi_{4}$ - order discrepancy handling, $\xi_{5}$ - operational information sharing).

The structural modeling revealed an R-square of 0.62 . The results suggest that the exogenous variables of personnel quality contact, timeliness, and operational information sharing were all significant and positive predictors of customer satisfaction at the $95 \%$ confidence level. The results show that the order condition is significant and positive at the $90 \%$ confidence level. The exogenous variables of ordering discrepancy handling were not significant predictors of customer satisfaction. The results of the SEM analysis are presented in Table $\mathbf{3}$ under Model 1. The results indicate the following:

Hypothesis 1 is supported, that is, the effect of personal contact quality on customer satisfaction $\left(+\right.$ ve $\left.\gamma_{1}\right)$ is significant.

Hypothesis 2 is supported, that is, the effect of timeliness on customer satisfaction (+ ve $\gamma_{2}$ ) is significant.

Hypothesis 3 is supported, that is, the effect of order condition on customer satisfaction ( + ve $\gamma_{3}$ ) is significant.

Hypothesis 4 is not supported, that is, the effect of order discrepancy handling on customer satisfaction (+ ve $\left.\gamma_{4}\right)$ is significant.

Hypothesis 5 is supported, that is, the effect of operational information sharing on customer satisfaction (+ ve $\gamma_{5}$ ) is significant.

Table 2 The estimates of measurement model

\begin{tabular}{|c|c|c|c|}
\hline \multirow{2}{*}{\multicolumn{4}{|c|}{$\begin{array}{l}\text { Construct } \\
\text { Customer Satisfaction }\left(n_{1}\right)\end{array}$}} \\
\hline & \multicolumn{3}{|c|}{ Customer Satisfaction ( $\left.\eta_{1}\right)$} \\
\hline S1 & $\lambda_{16}$ & 0.871 & 20.601 \\
\hline S2 & $\lambda_{26}$ & 0.905 & 19.485 \\
\hline S3 & $\lambda_{36}$ & 0.857 & $\left(\lambda_{36}\right.$ set to 1.0$)$ \\
\hline \multicolumn{4}{|c|}{ Personal Contact Quality $\left(\xi_{1}\right)$} \\
\hline PCQ1 & $\lambda_{11}$ & 0.751 & 14.946 \\
\hline PCQ2 & $\lambda_{21}$ & 0.858 & 17.734 \\
\hline PCQ3 & $\lambda_{31}$ & 0.876 & $\left(\lambda_{31}\right.$ set to 1.0$)$ \\
\hline \multicolumn{4}{|c|}{ Timeliness $\left(\xi_{2}\right)$} \\
\hline TI1 & $\lambda_{12}$ & 0.689 & 9.526 \\
\hline $\mathrm{T} 12$ & $\lambda_{22}$ & 0.763 & 9.997 \\
\hline $\mathrm{Tl} 3$ & $\lambda_{32}$ & 0.69 & $\left(\lambda_{32}\right.$ set to 1.0$)$ \\
\hline \multicolumn{4}{|c|}{ Order Condition $\left(\xi_{3}\right)$} \\
\hline OC1 & $\lambda_{13}$ & 0.668 & 12.045 \\
\hline OC2 & $\lambda_{23}$ & 0.868 & 15.198 \\
\hline OC3 & $\lambda_{33}$ & 0.847 & $\left(\lambda_{33}\right.$ set to 1.0$)$ \\
\hline \multicolumn{4}{|c|}{ Order Discrepancy Handling $\left(\xi_{4}\right)$} \\
\hline $\mathrm{ODH} 1$ & $\lambda_{14}$ & 0.74 & 14.306 \\
\hline $\mathrm{ODH} 2$ & $\lambda_{24}$ & 0.884 & 17.806 \\
\hline $\mathrm{ODH} 3$ & $\lambda_{34}$ & 0.845 & $\left(\lambda_{34}\right.$ set to 1.0$)$ \\
\hline \multicolumn{4}{|c|}{ Operational Information Sharing $\left(\xi_{5}\right)$} \\
\hline OIS1 & $\lambda_{15}$ & 0.749 & $\left(\lambda_{15}\right.$ set to 1.0$)$ \\
\hline OIS2 & $\lambda_{25}$ & 0.874 & 14.456 \\
\hline OIS3 & $\lambda_{35}$ & 0.77 & 12.998 \\
\hline
\end{tabular}



Operations and Supply Chain Management 13(1) pp. 1 - 10 @ 2020

In order to get a better picture of the critical role played by operational information sharing in the relationship between personal contact quality and customer satisfaction, we conducted a post hoc analysis with operational information sharing mediates the positive effect of the relationship between personal contact quality and customer satisfaction. The results of the SEM analysis are presented in Table 4 under Model 2. The global fit indices of the model (Anderson and Gerbing, 1988; Bagozzi and Yi, 1988; Bentler and Chou, 1987) are not as well as the ones found for Model $1(\chi 2=337.713, \mathrm{df}=123, \mathrm{p}$-value $=0$; RMSEA=0.076; RMSEA=0.076; NFI=0.921; NNFI=0.900; $\mathrm{CFI}=0.934 ; \mathrm{GFI}=0.893$; $\mathrm{AGFI}=0.852$ ). Different from the Model 1, the results show that order condition is significant and positive at the $95 \%$ confidence level, instead of $90 \%$ confidence level. The mediated relationship was verified by using the bootstrapping test (Cheung and Lau, 2007; Preacher and Hayes, 2008). The mediation effect was tested using 2000 bias corrected boot strapping resample's in AMOS. The direct and indirect effects were analyzed for potential partial mediation (discovered while fitting the model). Just indirect effects were analyzed for establishing full mediation. The results are summarized in Table $\mathbf{5}$.
Based on the results in Model 2, there is partial mediation between Personal Contact Quality and Operational Information Sharing. The mediation test shows that direct and indirect effect are both significant (see Table 4).

Additionally, to examine the role played by order discrepancy handling in the relationship between timeliness-customer satisfaction and order conditioncustomer satisfaction, we conducted a post hoc analysis with order discrepancy handling moderates the negative effect of the relationship between timeliness and customer satisfaction. The results of the SEM analysis are presented in Table 4 under Model 3. Goodness-of-fit indices in Model 3 is worse than the other two models. We plotted this interaction as shown in Figure 2. The results of the interaction tests are summarized in the Hypothesis Summary Table 3 . The results indicate that the moderating effect of order discrepancy handling between timeliness and customer satisfaction is significant, while the moderating effect of order discrepancy handling between order condition and customer satisfaction is insignificant. Based on the results in Model 3, Ordering Discrepancy Handling dampens the positive relationship between Timeliness and Customer Satisfaction (see Figure 2).

Table 3 Test of hypotheses: Estimates of structural equation model

\begin{tabular}{|c|c|c|c|c|c|c|c|}
\hline & & \multicolumn{2}{|c|}{ Model 1} & \multicolumn{2}{|c|}{ Model 2} & \multicolumn{2}{|c|}{ Model 3} \\
\hline \multicolumn{2}{|l|}{$\begin{array}{l}\text { Construct } \\
\text { Hypothesized Relationship }\end{array}$} & $\begin{array}{l}\text { Standard } \\
\text { Estimate }\end{array}$ & t-Value & $\begin{array}{l}\text { Standard } \\
\text { Estimate }\end{array}$ & t-Value & $\begin{array}{l}\text { Standard } \\
\text { Estimate }\end{array}$ & t-Value \\
\hline $\begin{array}{l}\text { (H1) Personal Contact Quality } \rightarrow \\
\text { Customer Satisfaction }\end{array}$ & $\gamma_{1}$ & 0.22 & 3.267 & 0.20 & 2.204 & 0.20 & 3.451 \\
\hline $\begin{array}{l}\text { (H2) Timeliness } \rightarrow \\
\text { Customer Satisfaction }\end{array}$ & $\gamma_{2}$ & 0.21 & 3.111 & 0.27 & 3.406 & 0.27 & 2.763 \\
\hline $\begin{array}{l}\text { (H3) Order Condition } \rightarrow \\
\text { Customer Satisfaction }\end{array}$ & $\gamma_{3}$ & 0.11 & 1.873 & 0.13 & 2.261 & 0.13 & 1.808 \\
\hline $\begin{array}{l}\text { (H4) Order Discrepancy Handling } \rightarrow \\
\text { Customer Satisfaction }\end{array}$ & $\gamma_{4}$ & 0.01 & 0.110 & 0.04 & 0.511 & - & - \\
\hline $\begin{array}{l}\text { (H5) Operational Information Sharing } \rightarrow \\
\text { Customer Satisfaction }\end{array}$ & $\gamma_{5}$ & 0.43 & 5.362 & $\begin{array}{l}0.42 \\
\left(\beta_{1}\right)\end{array}$ & 9,218 & 0.44 & 5.639 \\
\hline $\begin{array}{l}\text { (H1a) Personal Contact Quality } \rightarrow \\
\text { Operational Information Sharing }\end{array}$ & $\gamma_{11}$ & - & - & 0.62 & 6.134 & - & - \\
\hline$(\mathrm{H} 4 \mathrm{a}) \mathrm{ODH} \_\mathrm{x} \_\mathrm{TI} \rightarrow$ Customer Satisfaction & $\gamma_{41}$ & - & - & - & - & 0.62 & -3.314 \\
\hline \multicolumn{2}{|l|}{ Fit Indices } & \multicolumn{2}{|c|}{ Model 1} & \multicolumn{2}{|c|}{ Model 2} & \multicolumn{2}{|c|}{ Model 3} \\
\hline $\begin{array}{l}\text { Ch.Sq. } \\
\text { Df } \\
\text { CMIN/df } \\
\text { p-value } \\
\text { RMSEA } \\
\text { GFI } \\
\text { AGFI } \\
\text { NFI } \\
\text { NNFI } \\
\text { CFI } \\
\text { Squared Multiple Correlations }\left(\mathrm{R}^{2}\right)\end{array}$ & & & & & & & \\
\hline
\end{tabular}

Table 4 Testing results of mediating effects of operational information sharing in model 2

\begin{tabular}{lllll}
\hline Hypothesis & Direct Beta w/o Med & Direct Beta w/Med & Indirect Beta & $\begin{array}{c}\text { Mediation } \\
\text { observed }\end{array}$ \\
\hline $\begin{array}{l}\text { Med } \\
\text { PCQ- OIS-CS }\end{array}$ & $.26^{* * *}$ & $.199^{*}$ & $0.263^{* * *}$ & Partial mediation \\
\hline $\begin{array}{l}* \\
\text { confidence level }\end{array}$ & & &
\end{tabular}




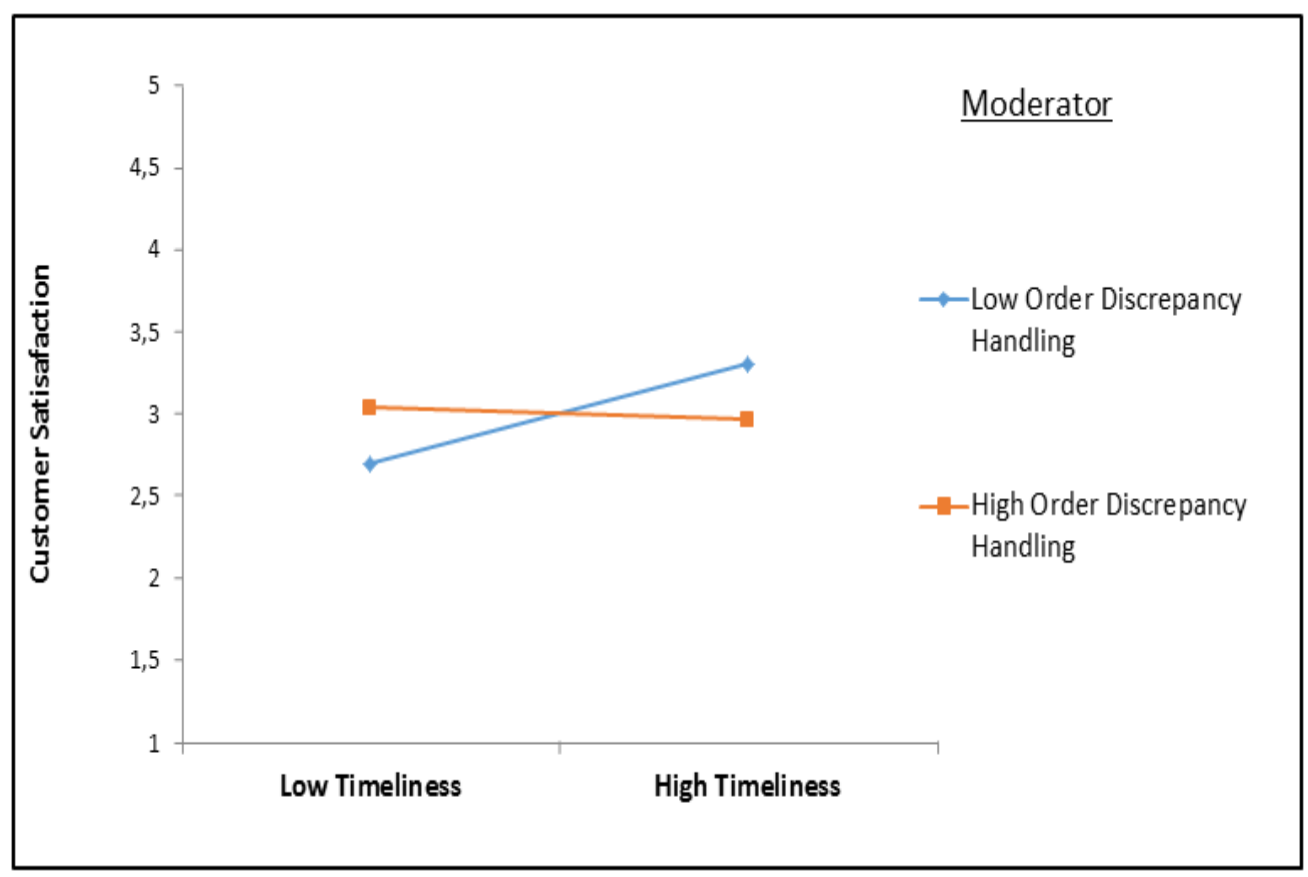

Figure 2 Moderating effects of order discrepancy handling between timeliness and customer satisfaction

\section{CONCLUSION, LIMITATIONS, AND FUTURE RESEARCH}

This research was conducted to investigate the customers' satisfaction in logistics services from the perspective of logistics service quality factors. The results indicate that there are significant relationships between the Timeliness, Order Condition, Personnel Contact Quality, Operational Information Sharing and perception of Customer Satisfaction in logistics services. These results indicate that Timeliness and Order Condition, which are leading two dimensions of physical distribution service quality (Mentzer et al., 2001), still sustain their importance in LSQ. Also, results show that Personnel Contact Quality, which is one of the main three dimensions of service quality (Lehtinen and Lehtinen, 1991), has a significant impact on the perception of satisfaction. Additionally, we found that operational information sharing mediates the positive effect of the relationship between personal contact quality and customer satisfaction. Based on the results in Model 2, there is partial mediation between Personal Contact Quality and Operational Information Sharing. We found that order discrepancy handling moderates the negative effect of the relationship between timeliness and customer satisfaction. Based on the results in Model 3, Ordering Discrepancy Handling dampens the positive relationship between Timeliness and Customer Satisfaction.

This research, through its empirical testing, also extends the understanding of LSQ in the era of information share. Unlike previous studies, we also examined the effect of operational information sharing by logistics services, which is getting more significant in today's information era, on the perception of customers' satisfaction. Logistics companies have to understand customers' changing attitudes and desires to get the competitive advantage in the market. Without understanding primary factors that behind their behavioral intentions, it is hard to survive in the market for logistics companies. A contribution of this paper is that operational information sharing with customers positively affects the perception of customer satisfaction. Finding out desires of clients can create new services to generate value for customers and able to make more attractive of their services for them. Additionally, empirical results show that e-mail, applications (Android, iOS, Windows Mobile), and SMS are the most used tools for interaction with customers.

Still, this study has some limitations. One of the limitations is the data was collected from sample frame of University of North Texas' College of Business students. Additionally, we only examined these LSQ factors from the view of business to customer perspective. In the future, we can expand this study business to business (B2B) framework and we can comparison different industry types to identify logistics service quality factors. Additionally, in B2B context we can expand this study by investigating other Mentzer's (1999) LSQ factors; order accuracy, ordering procedure, order quality. Considering structural modeling results of this study which revealed only $62 \%$ of customers' satisfaction (R square of 0.62) in LSQ, in future research, we can develop new LSQ constructs, and we can investigate the validation of these constructs by EFA and CFA.

Finally, any company who wants to create a competitive advantage in business should give importance to satisfy customers' desires. Therefore, logistics companies cannot build any long-term relationship without understanding the fundamental factors behind the customers' behavioral intentions. One of the business implications of this research, logistics service providers can easily target what areas to concentrate for the purpose of the improve their LSQ. Additionally, by getting feedback from their customers, firms can easily enhance their service quality and can build a long-term relationship with their customers by meeting their expectations.' 


\section{REFERENCES}

Anderson, J. C., \& Gerbing, D. W. (1988). Structural equation modeling in practice: $\mathrm{A}$ review and recommended two-step approach. Psychological bulletin, 103(3), pp. 411-423.

Bagozzi, R. P., \& Yi, Y. (1988). On the evaluation of structural equation models. Journal of the Academy of Marketing Science, 16(1), pp. 74-94.

Bentler, P. M. (1990). Comparative fit indexes in structural models. Psychological Bulletin, 107(2), pp. 238-246.

Bienstock, C. C., Mentzer, J. T., \& Bird, M. M. (1996). Measuring physical distribution service quality. Journal of the Academy of Marketing Science, 25(1), pp. 31-44.

Bienstock, C. C., Royne, M. B., Sherrell, D., \& Stafford, T. F. (2008). An expanded model of logistics service quality: Incorporating logistics information technology. International Journal of Production Economics, 113(1), pp. 205-222.

Bienstock, C.C., Stafford, M.R. \& Stafford, T.F. (2015). The role of technology in industrial customers' perceptions of logistics service quality and their future purchase intentions. In Revolution in marketing: Market driving changes, pp. 122-122.

Bitner, M. J., Booms, B. H., \& Mohr, L. A. (1994). Critical service encounters: The employee's viewpoint. the Journal of Marketing, 58(4), pp. 95-106.

Bowersox, D. J., Closs, D. J., \& Cooper, M. B. (2002). Supply chain logistics management. McGraw-Hill New York, NY.

Bowersox, D. J., Mentzer, J. T., \& Speh, T. W. (2008). Logistics Leverage. Journal of Business Strategies, 25(2), pp. 85-99.

Coyle, J. J., Bardi, E. J., \& Langley, C. J. (1996). The management of business logistics. (Vol. 6): West Publishing Company St Paul, MN.

Daugherty, P. J., Stank, T. P., \& Ellinger, A. E. (1998). Leveraging logistics/distribution capabilities: the effect of logistics service on market share. Journal of Business Logistics, 19(2), pp. 35-51.

Feng, Y.-X., Zheng, B., \& Tan, J.-r. (2007). Exploratory study of logistics service quality scale based on online shopping malls. Journal of Zhejiang University Science A, 8(6), pp. 926-931.

Fornell, C., \& Larcker, D. F. (1981). Structural equation models with unobservable variables and measurement error: Algebra and statistics. Journal of Marketing Research, 18(3), pp. 382-388.

Glenn Richey Jr, R., \& Savitskie, K. (2007). Internal and external logistics information technologies: the performance impact in an international setting. International Journal of Physical Distribution \& Logistics Management, 37(6), pp. 454-468.

Hair, J. F., W. C. Black,, B. J., Babin, and R. E. Anderson. (2010). Multivariate Data Analysis (7th ed.). NJ: Prentice Hall.
Hurley, R. F., Giunipero, L. C., \& Nichols, E. L. (2000). Organizational Learning in Global Purchasing: A Model and Test of Internal Users and Corporate Buyers. Decision sciences, 31(2), pp. 293-325.

Innis, D. E., \& La Londe, B. J. (1994). Customer service: the key to customer satisfaction, customer loyalty, and market share. Journal of Business Logistics, 15(1), pp. $1-27$.

Kilibarda, M., Nikolicic, S. \& Andrejic, M. (2016). Measurement of logistics service quality in freight forwarding companies: a case study of the Serbian market. The International Journal of Logistics Management, 27(3), pp.770-794.

Lehtinen, U., \& Lehtinen, J. R. (1991). Two approaches to service quality dimensions. Service Industries Journal, 11(3), pp. 287-303.

Meidutè-Kavaliauskienè, I., Aranskis, A., \& Litvinenko, M. (2014). Consumer satisfaction with the quality of logistics services. Procedia-Social and Behavioral Sciences, 110, pp. 330-340.

Mentzer, J. T., Flint, D. J., \& Hult, G. T. M. (2001). Logistics service quality as a segment-customized process. Journal of Marketing, 65(4), pp. 82-104.

Mentzer, J. T., Flint, D. J., \& Kent, J. L. (1999). Developing a logistics service quality scale. Journal of Business Logistics, 20(1), pp. 9-32.

Mentzer, J. T., Myers, M. B., \& Cheung, M.-S. (2004). Global market segmentation for logistics services. Industrial Marketing Management, 33(1), pp. 15-20.

Murfield, M., Boone, C.A., Rutner, P. \& Thomas, R. (2017). Investigating logistics service quality in omnichannel retailing. International Journal of Physical Distribution \& Logistics Management, 47(4), pp.263296.

Novack, R. A., Langley Jr, C. J., \& Rinehart, L. M. (1995). Creating logistics value: themes for the future.

Parasuraman, A., Zeithaml, V. A., \& Berry, L. L. (1985). A conceptual model of service quality and its implications for future research. Journal of Marketing, 49(4), pp. 41-50.

Rafiq, M., \& Jaafar, H. S. (2007). Measuring customers'perceptions of logistics service quality of $3 \mathrm{pl}$ service providers. Journal of Business Logistics, 28(2), pp. 159-175.

Soh, K.L., Chin, S.H. \& Wong, W.P. (2015). A theoretical model to investigate customer loyalty on logistics service providers for sustainable business performance. International Journal of Business Performance and Supply Chain Modelling, 7(3), pp. 212-232.

Sohn, J.-I., Woo, S.-H. A \& Kim, T.-W. (2017). Assessment of logistics service quality using the Kano model in a logistics-triadic relationship. International Journal of Logistics Management, 28(2), pp. 680-698. 


\section{APPENDIX 1}

Appendix A. Demographic distribution of the sample

\begin{tabular}{lll}
\hline Demographic Profile & Total & Percent \\
\hline Gender & & 49 \\
Male & 148 & 51 \\
Female & 154 & 56.3 \\
Age & & 26.8 \\
$18-22$ & 170 & 5 \\
$23-27$ & 81 & 11.9 \\
$28-32$ & 15 & 16.2 \\
32 and Over & 36 & 57 \\
Occupation & & 26.8 \\
Full-time work & 9 & 0.7 \\
Part-time work & 172 & 4.3 \\
Unemployed & 81 & 34.1 \\
Academic Status & & 45.3 \\
Freshman & 2 & 12.6 \\
Sophomore & 13 & \\
Junior & 163 & 146 \\
Senior & 38 & \\
Graduate & & \\
\hline
\end{tabular}

Appendix B. LSQ Instrument and Corresponding Scale Items

\begin{tabular}{|c|c|c|}
\hline Scale & Question & Source \\
\hline \multicolumn{3}{|c|}{ Personal Contact Quality } \\
\hline PCQ1 & Contact employees make an effort to understand my situation & Bienstock et al. (2008) \\
\hline PCQ2 & Contact employees can resolve product/service problems. & Bienstock et al. (2008) \\
\hline PCQ3 & The service knowledge/experience of contact employees is sufficient. & Bienstock et al. (2008) \\
\hline \multicolumn{3}{|c|}{ Timeliness } \\
\hline TI1 & The time between placing requisition and receiving delivery is short. & Mentzer et al. (2001) \\
\hline TI2 & Deliveries arrive on the date promised & Mentzer et al. (2001) \\
\hline $\mathrm{TI} 3$ & The amount of time a requisition is on back-order is short. & Mentzer et al. (2001) \\
\hline \multicolumn{3}{|c|}{ Order Discrepancy Handling } \\
\hline $\mathrm{ODH} 1$ & Correction of delivered quality discrepancies is satisfactory. & Mentzer et al. (2001) \\
\hline $\mathrm{ODH} 2$ & The process of reporting of discrepancy process is adequate. & Mentzer et al. (2001) \\
\hline $\mathrm{ODH} 3$ & The response to order discrepancies is satisfactory. & Mentzer et al. (2001) \\
\hline \multicolumn{3}{|c|}{ Order Condition } \\
\hline OC1 & Order received from logistics services is undamaged. & Mentzer et al. (2001) \\
\hline OC2 & Order damage rarely occurs as a result of the transport mode. & Mentzer et al. (2001) \\
\hline OC3 & Order damage rarely occurs as a result of the transport carrier handling. & Mentzer et al. (2001) \\
\hline \multicolumn{3}{|c|}{ Operational Information Sharing } \\
\hline OIS1 & Operational information is sharing effectively with customers. & Glenn and Savitskie (2007) \\
\hline OIS2 & $\begin{array}{l}\text { Services have an adequate ability to share both standardized and customized } \\
\text { information externally with customers. }\end{array}$ & Glenn and Savitskie (2007) \\
\hline OIS3 & The information is accurate, timely and formatted to facilitate use. & Glenn and Savitskie (2007) \\
\hline OIS4 & Real time information about shipping can be access anytime. & Author \\
\hline \multicolumn{3}{|c|}{ Satisfaction } \\
\hline S1 & $\begin{array}{l}\text { What is your general impression of the logistics service provider? } \\
(1=\text { "terrible", } 5 \text { = "excellent") }\end{array}$ & Mentzer et al. (2001) \\
\hline S2 & $\begin{array}{l}\text { Which words does best describe your feelings toward logistics service provider? } \\
\text { (1 = "very dissatisfied," } 5 \text { = "very satisfied") }\end{array}$ & Mentzer et al. (2001) \\
\hline S3 & $\begin{array}{l}\text { How satisfied are you with logistics service provider? } \\
\text { "very satisfied") }\end{array}$ & Mentzer et al. (2001) \\
\hline
\end{tabular}


Hasan Uvet is an Assistant Professor of Supply Chain Mnagement in the School of Business at Georgia Gwinnet College. He received his Ph.D. degree in Logistics Systems at the University of North Texas. He holds a Bachelor of Science in System Engineering from Turkish Military Academy, Ankara Turkey and Master of Science in International Security Strategy Management and Leadership from Turkish Army War College, Istanbul, Turkey. His research focuses on supply chain collaboration, performance-based logistics, logistics service quality, and supply chain resiliency. 